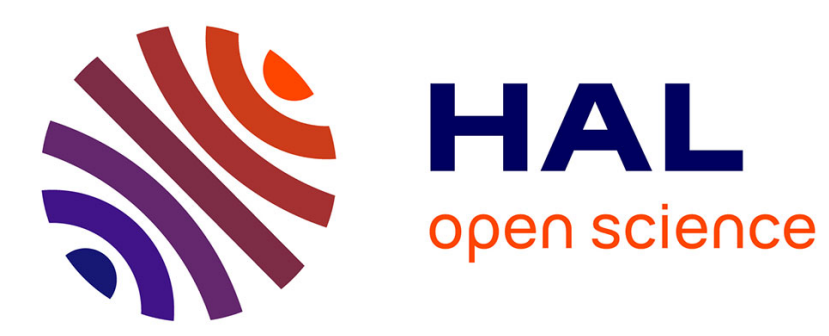

\title{
Covalently linked donor-acceptor dyad for efficient single material organic solar cells
}

Sebastian Lucas, Tim Leydecker, Paolo Samori, Elena Mena-Osteritz, Peter

Bäuerle

\section{- To cite this version:}

Sebastian Lucas, Tim Leydecker, Paolo Samori, Elena Mena-Osteritz, Peter Bäuerle. Covalently linked donor-acceptor dyad for efficient single material organic solar cells. Chemical Communications, 2019, 55 (94), pp.14202-14205. 10.1039/C9CC07179B . hal-02509599

\section{HAL Id: hal-02509599 \\ https://hal.science/hal-02509599}

Submitted on 16 Mar 2020

HAL is a multi-disciplinary open access archive for the deposit and dissemination of scientific research documents, whether they are published or not. The documents may come from teaching and research institutions in France or abroad, or from public or private research centers.
L'archive ouverte pluridisciplinaire HAL, est destinée au dépôt et à la diffusion de documents scientifiques de niveau recherche, publiés ou non, émanant des établissements d'enseignement et de recherche français ou étrangers, des laboratoires publics ou privés. 


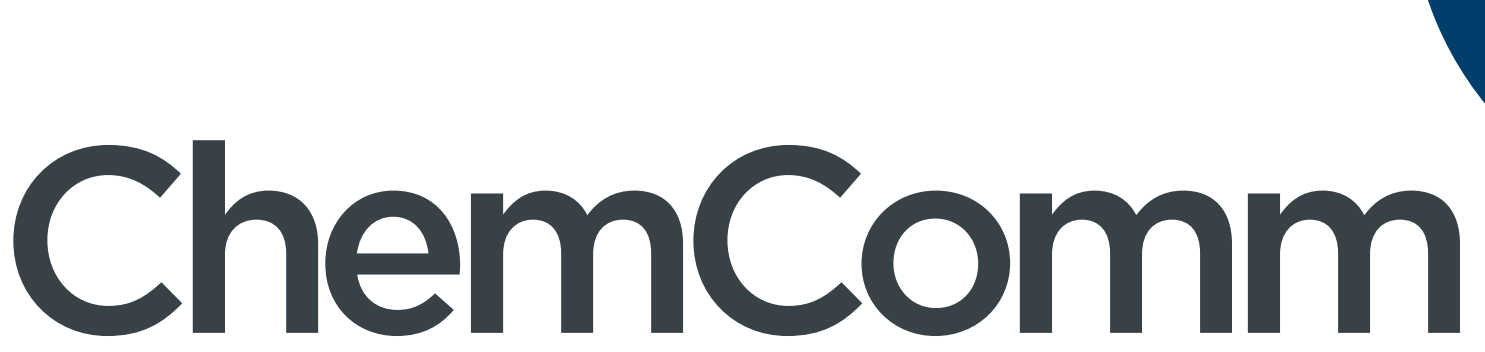

Chemical Communications

\section{Accepted Manuscript}

This article can be cited before page numbers have been issued, to do this please use: P. Baeuerle, S. Lucas, T. Laydecker, P. Samorì and E. Mena-Osteritz, Chem. Commun., 2019, DOI:

10.1039/C9CC07179B.
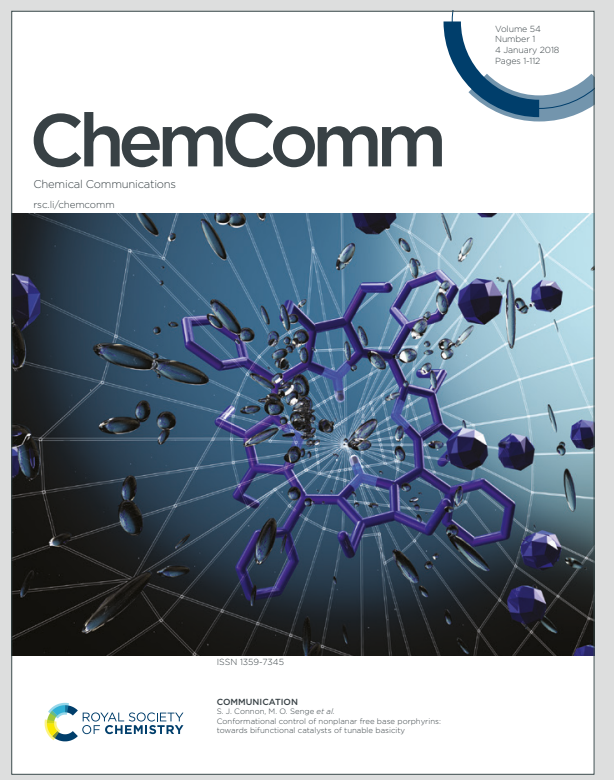

This is an Accepted Manuscript, which has been through the Royal Society of Chemistry peer review process and has been accepted for publication.

Accepted Manuscripts are published online shortly after acceptance, before technical editing, formatting and proof reading. Using this free service, authors can make their results available to the community, in citable form, before we publish the edited article. We will replace this Accepted Manuscript with the edited and formatted Advance Article as soon as it is available.

You can find more information about Accepted Manuscripts in the Information for Authors.

Please note that technical editing may introduce minor changes to the text and/or graphics, which may alter content. The journal's standard Terms \& Conditions and the Ethical guidelines still apply. In no event shall the Royal Society of Chemistry be held responsible for any errors or omissions in this Accepted Manuscript or any consequences arising from the use of any information it contains. 


\title{
COMMUNICATION
}

\section{Covalently Linked Donor-Acceptor Dyad for Efficient Single Material Organic Solar Cells}

Received 00th January 20xx,

\author{
Sebastian Lucas, ${ }^{a}$ Tim Leydecker, ${ }^{b}$ P. Samorì, ${ }^{b}$ Elena Mena-Osteritz, ${ }^{a}$ Peter Bäuerle ${ }^{\star a}$
}

Accepted 00th January 20xx

DOI: $10.1039 / \times 0 \times x 00000 x$

\begin{abstract}
A novel covalently linked donor-acceptor dyad comprising a dithienopyrrol-based oligomeric donor and a fullerene acceptor was synthesized and characterized. The concomitant effect of favorable optoelectronic properties, energy levels of the frontier orbitals, and ambipolar charge transport enabled the application of the dyad in simplified solution-processed single material organic solar cells reaching a power conversion efficiency of $3.4 \%$.
\end{abstract}

Power conversion efficiencies (PCE) for lab-scale solution-processed bulk heterojunction organic solar cells (BHJSC) increased to over $16 \%$ by blending a donor polymer and a non-fullerenic acceptor in the photoactive layer. ${ }^{1}$ Such high-performance BHJSCs are extensively optimized via improvement of the molecular structure of donor (D) and acceptor (A), their mixing ratio, solvents, additives, processing conditions, and post-treatment methods. ${ }^{2}$ The control over the active layer morphology yielding favorable nanophase separation of $D$ and $A$ assemblies into an interpenetrating network is notably challenging. Though the problem arises that the optimized biphasic morphology is typically thermodynamically metastable leading to decreased performance and long-term stability of the solar cell. ${ }^{3}$

Despite the performance of single material organic solar cells (SMOSC) is still behind conventional BHJSCs, ${ }^{4}$ their reduced processing complexity represents tremendous advantages, because only one photoactive material has to be deposited. Moreover, film morphology is stabilized compared to conventional biphasic BHJSCs leading to improved thermal and photochemical long term stability. ${ }^{5}$

Pioneering SMOSCs were prepared in 2000 by Nierengarten et al. by sandwiching oligophenylenevinylene (D)-fullerene $C_{60}(A)$ dyads between two electrodes showing a weak photovoltaic effect of $0.03 \%$ PCE under monochromatic light illumination. ${ }^{6}$ Janssen et al. then introduced the so-called 'double cable' polymers by linking $C_{60}$ bearing side chains to a conjugated poly(phenylenevinylene) donor polymer, which in standard solar cells reached PCEs of $0.1 \% .{ }^{7}$ During the following decade, SMOSCs were only slowly improved to PCEs of $1.5 \%,{ }^{8}$ thus reducing the

\footnotetext{
anstitute of Organic Chemistry II and Advanced Materials, University of Ulm,

Albert-Einstein-Allee 11, 89081 UIm, Germany

b. University of Strasbourg, CNRS, ISIS, 8 allée Gaspard Monge, 67000 Strasbourg,

France.

Electronic Supplementary Information (ESI) available
}

interest of the scientific community in this approach. According to Roncali's and Grosu's comprehensive recent review article, ${ }^{4}$ a renaissance of SMOSCs based on covalently linked D-A materials started. Very recently, with 6.3\% PCE for a benzodithiophene (D)-based 'double cable' polymer functionalized with perylene diimide $(A)$ side chains, impressive progress has been achieved. ${ }^{9}$ The improved thermal and photochemical stability will be attractive for technological production of stable printed largescale OSCs. ${ }^{5,9}$

Alongside this widely employed molecular design of D-A 'double cable' polymers, other construction principles for photoactive single materials have been developed. Structurally defined (co)oligomers have proven certain advantages over polymers, ${ }^{10}$ thus, various molecular D-A systems were implemented into SMOSCs. ${ }^{4}$ A PCE of $2.7 \%$ was reached for a co-oligomeric donor, which was linked as in the 'double cable' approach for polymers to perylene diimides via flexible linkers. ${ }^{11}$ Direct connection of perylene diimide to this donor unit led to a fully conjugated DA system achieving a lower PCE of $1.8 \% .^{12}$ Very recently, Min et al. disclosed a benzodithiophene-cored D-A molecule terminally connected to fullerene $C_{70}$ reaching $3.22 \% \mathrm{PCE}^{13}$ which is higher than the directly comparable A-D-A molecule of Woo et al. bearing two pendant $\mathrm{C}_{60}$ wings (PCE 2.44\%). ${ }^{14}$

The topic of SMOSCs is scientifically highly interesting because it is still unclear, how the fundamental physical elementary processes such as exciton formation, diffusion, dissociation, polaron formation, and charge transport, which are well investigated for biphasic BHJSCs, ${ }^{10}$ proceed in the small-sized D-A molecules and aggregates concomitant with the question, how the crucial phase-separated morphology and the D-A interfaces are formed. In particular, it is surprising that geminate recombination of charges is not the overall process.

In this communication, we describe synthesis and characterization of ambipolar D-A dyad $\mathbf{1}$ consisting of a dithienopyrrole (DTP)-based co-oligomer as donor and fullerene $\mathrm{PC}_{61} \mathrm{BM}$ as acceptor which are linked by a flexible alkyl chain containing an ester group resulting in a spacer of ten atoms between $D$ and $A$ unit. The DTP-donor part was chosen according to its excellent 
performance in biphasic BHJSCs with $\mathrm{PC}_{71} \mathrm{BM}$ as acceptor. ${ }^{15} \mathrm{Im}$ plementation of dyad $\mathbf{1}$ as single photoactive component into SMOSCs gave PCEs of $3.4 \%$ after solvent vapor annealing (SVA) which is a higher value than for the known D-A oligomers. Ambipolar charge transport is operative in this new material and film morphology was investigated.

The synthetic route to D-A dyad $\mathbf{1}$ is shown in Scheme 1 , and detailed synthetic procedures are given in the Electronic Supporting Information (ESI). Similar to Lutkenhaus' synthesis of the corresponding C3-derivative, ${ }^{16}$ we now extended the route and reacted 3,3'-dibromo-2,2'-bithiophene 1 with triisopropylsilyl (TIPS)-protected 4-aminobutan-1-ol $\mathbf{2}$ in a twofold Pd-catalyzed Buchwald-Hartwig amination to give functionalized DTP 3 in $94 \%$ yield. After twofold stannylation of DTP 3 to bisstannyl 4 in quantitative yield, the latter was reacted with 5'-bromo-3,4'dihexyl-2,2'-bithiophene-5-carbaldehyde $5^{17}$ to give co-oligomeric dialdehyde 6 in $69 \%$ yield. Deprotection of the side chain TIPS group in $\mathbf{6}$ with tetrabutylammonium fluoride resulted in alcohol 7 (80\% yield) which was converted in a Knoevenagel condensation with malononitril to dicyanovinyl derivative 8 in $79 \%$ yield comprising the typical A-D-A structure of co-oligomers effective in organic solar cells. ${ }^{18,19}$ In a final step, the alcohol-functionalized donor $\mathbf{8}$ was connected to fullerene phenyl[C61]butyric acid ( $\left.\mathrm{PC}_{61} \mathrm{BA}\right) \mathbf{9}$ in a Steglich esterification furnishing D-A dyad 1 in $69 \%$ yield. For the whole synthetic sequence, an overall yield of $27 \%$ over six steps was achieved allowing for preparation on larger scale.
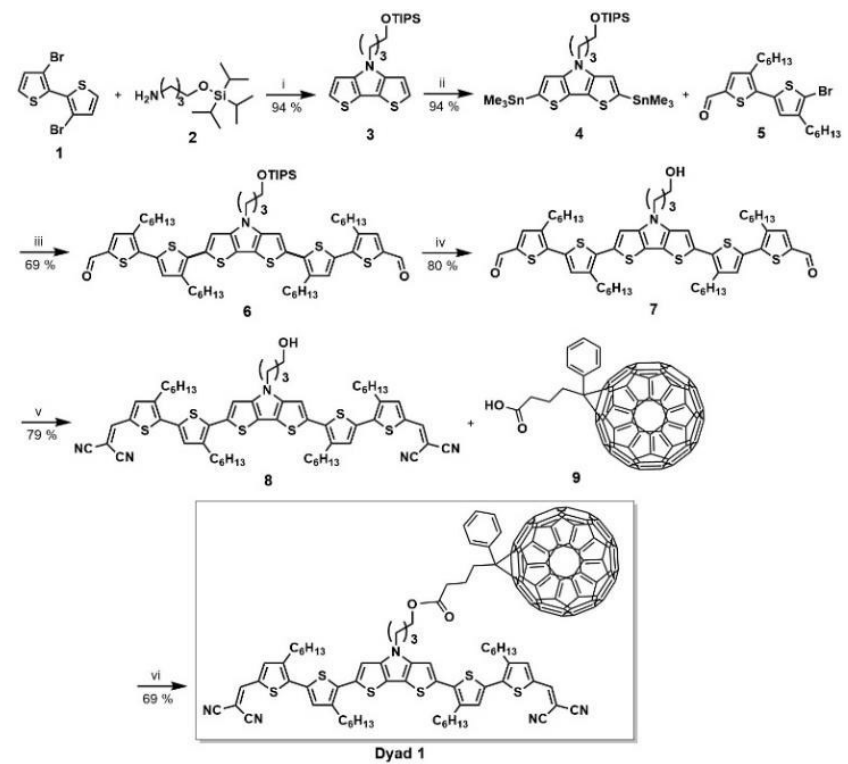

Scheme 1 Synthetic route for the preparation of dyad 1. (i) $\operatorname{Pd}_{2}\left(d_{b a}\right)_{3}$ BINAP, NaOtBu, toluene, $110{ }^{\circ} \mathrm{C}, 24 \mathrm{~h}$; (ii) 1. $n$-BuLi, THF, $-78^{\circ} \mathrm{C}, 2 \mathrm{~h}, 2$ $\mathrm{Me}_{3} \mathrm{SnCl}, \mathrm{THF},-78{ }^{\circ} \mathrm{C}$ to r.t., $24 \mathrm{~h}$; (iii) $\mathrm{Pd}\left(\mathrm{PPh}_{3}\right)_{4}, \mathrm{DMF}, 85^{\circ} \mathrm{C}, 24 \mathrm{~h}$; (iv) TBAF, DCM, $25^{\circ} \mathrm{C}, 21 \mathrm{~d}$; (v) malononitrile, $\mathrm{NH}_{4} \mathrm{OAC}, \mathrm{DCE}, 80^{\circ} \mathrm{C}, 48 \mathrm{~h}$; (vi) $E D C \times \mathrm{HCl}$, DMAP, TEA, $\mathrm{CS}_{2} / \mathrm{DCB}, 4$ d, r.t.

The structures of precursor $\mathbf{8}$ and D-A dyad $\mathbf{1}$ were confirmed by ${ }^{1} \mathrm{H}$ - and ${ }^{13} \mathrm{C}-\mathrm{NMR}$ spectroscopy (Fig. S1-S4) and high resolution mass spectra (HRMS) (Fig. S5-S6). Dyad $\mathbf{1}$ is thermally very stable and showed a decomposition temperature of $>392{ }^{\circ} \mathrm{C}$ measured by thermal gravimetric analysis (TGA) (Fig. S7). Differential scanning calorimetry (DSC) revealed a relatively broad melting range of $105-115^{\circ} \mathrm{C}$ in the forward scan.
The same behaviour has been seen for other D-A molecules with similar middle-sized spacer length $D$ Betwee and fullerene indicating suppressed crystallization by the fullerene 'arm'. ${ }^{13,20}$ Only for much longer spacers, e.g. 24 atoms, signals in DSC and powder diffraction were identified. ${ }^{21} \mathrm{~A}$ recrystallization peak is observed at $186^{\circ} \mathrm{C}$ in the back scan (Fig. S8). The excellent solubility of dyad 1 in solvents such as o-xylene, chloroform, or THF $(55-75 \mathrm{mg} / \mathrm{mL})$ allows for characterization of electronic properties and for preparation of thin films.

The optical properties of D-A dyad $\mathbf{1}$ were determined by UVvis and emission spectra measured in dichloromethane (DCM) solution at room temperature and in thin films. The main absorption band with a maximum at $632 \mathrm{~nm}$ in the film spectrum is attributed to a charge transfer (CT) of the A-D-A-type donor unit, whereas the absorption at $417 \mathrm{~nm}$ is assigned to the $\pi-\pi^{*}$-transition of the oligomeric backbone. The band at highest energy showing a maximum at $335 \mathrm{~nm}$ is due to the absorption of the fullerene subunit. An optical energy gap of $1.54 \mathrm{eV}$ was determined (Table 1, Fig.1 left). The absorption progression of D-A dyad $\mathbf{1}$ is more or less a superimposition of the spectra of the individual units, reference 8 and $\mathrm{PC}_{61} \mathrm{BM}$, which was taken as soluble fullerene derivative, whereupon the maxima of the donor moiety in $\mathbf{1}$ are slightly blue-shifted relative to 8 . The emission maxima were found at $812 \mathrm{~nm}$ in solution and at $874 \mathrm{~nm}$ in thin films, respectively (Fig. S9).
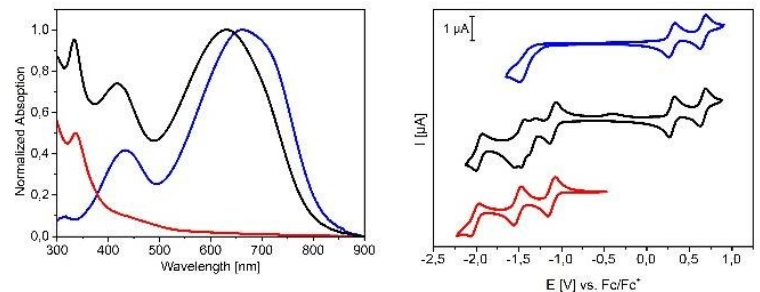

Fig. 1 Thin film absorption spectra spin-coated on glass from chloroform solution (left) and cyclic voltammograms in dichloromethane $\left(c \approx 1 \times 10^{-3}\right.$ $\mathrm{M})$, TBAPF $_{6}$ as supporting electrolyte $(0.1 \mathrm{M})$, scan speed $100 \mathrm{mV} \mathrm{s}^{-1}$ (right) of dyad 1 (black), donor precursor 8 (blue), and $\mathrm{PC}_{61} \mathrm{BM}$ (red).

Table 1 Optical properties of dyad 1, precursor 8, and $\mathrm{PC}_{61} \mathrm{BM}$.

\begin{tabular}{c|cccc|cc}
\hline & $\begin{array}{c}\lambda_{\mathrm{max}^{\mathrm{sol}}} \\
{[\mathrm{nm}]^{\mathrm{a}}}\end{array}$ & $\begin{array}{c}\varepsilon \\
{\left[\mathrm{Lmol}^{-}\right.} \\
\left.{ }^{1} \mathrm{~cm}^{-1}\right]^{\mathrm{a}}\end{array}$ & $\begin{array}{c}\lambda_{\max }{ }^{\mathrm{em}} \\
{[\mathrm{nm}]^{\mathrm{a}}}\end{array}$ & $\begin{array}{c}\mathrm{E}_{\mathrm{g}}{ }^{\mathrm{sol}} \\
{[\mathrm{eV}]^{\mathrm{b}}}\end{array}$ & $\begin{array}{c}\lambda_{\mathrm{max}} \\
{[\mathrm{nm}]^{\mathrm{c}}}\end{array}$ & $\begin{array}{c}\mathrm{E}_{\mathrm{g}}{ }^{\text {film }} \\
{[\mathrm{eV}]^{\mathrm{b}, \mathrm{c}}}\end{array}$ \\
\hline Dyad 1 & $\begin{array}{c}562,395, \\
328\end{array}$ & 55738 & 812 & 1.81 & $\begin{array}{c}632,417, \\
335\end{array}$ & 1.54 \\
$\mathbf{8}$ & 562,399 & 55052 & 810 & 1.81 & 662,437 & 1.52 \\
$\mathrm{PC}_{61} \mathrm{BM}$ & 329,261 & 46000 & - & 2.76 & 338 & 2.10 \\
\hline
\end{tabular}

a Measured in dichloromethane, maxima underlined. ${ }^{\mathrm{b}}$ Taken from onset of absorption and calculated by $E_{g}=1240 / \lambda$. ${ }^{~ T h i n ~ f i l m s ~ b y ~ s p i n-c o a t i n g ~}$ from chloroform solution on glass.

The electrochemical properties of the three compounds were determined by cyclic voltammetry in dichloromethane solution with tetrabutylammonium hexafluorophosphate $(0.1 \mathrm{M})$ as supporting electrolyte (Fig. 1, right). Potentials are referenced vs ferrocene/ferricenium $\left(\mathrm{Fc} / \mathrm{Fc}^{+}\right)$and listed in Table 2. For dyad $\mathbf{1}$ two reversible oxidation waves with potentials at $0.25 \mathrm{~V}$ and $0.61 \mathrm{~V}$ were found indicating the formation of stable radical cations and dications at the donor backbone and well coincide with the oxidation potentials of precursor $\mathbf{8}$. In the reductive regime, 
four reduction peaks are identified for linked dyad 1 . Three of them at $-1.12 \mathrm{~V},-1.52 \mathrm{~V}$, and $-2.02 \mathrm{~V}$ correspond to the successive reduction of the fullerene subunit, whereas the potential at $-1.39 \mathrm{~V}$ belongs to the reduction of the dicyanovinylene (DCV) end groups of the donor backbone. The assignment was made possible through comparison with the individual CVs of the subunits 8 and $\mathrm{PC}_{61} \mathrm{BM}$. From the onset of the first oxidation and reduction potential the energy of the electrochemical gap and of the HOMO and LUMO frontier orbitals were calculated which are important for the application of the materials in organic solar cells. Thus, the HOMO energy of dyad $\mathbf{1}$ and reference $\mathbf{8}$ were found at around $-5.30 \mathrm{eV}$ whereas the LUMO energy of 1 (-4.03 $\mathrm{eV}$ ) corresponds to that of $\mathrm{PC}_{61} \mathrm{BM}$ resulting in an energy gap of $1.27 \mathrm{eV}$. The optoelectronic properties of dyad 1, strong absorption from 400 to $850 \mathrm{~nm}$ and ideal energy levels, should allow for the successful implementation into SMOSCs.

Table 2 Electrochemical properties and energy levels of the frontier orbitals of dyad $\mathbf{1}$ in comparison to precursor $\mathbf{8}$ and $\mathrm{PC}_{61} \mathrm{BM}$.

\begin{tabular}{c|c|c|cc}
\hline & $\begin{array}{c}\mathrm{E}_{1 / 2} \mathrm{Ox}^{1 / 2} \\
{[\mathrm{~V}]^{\mathrm{a}}}\end{array}$ & $\begin{array}{c}\mathrm{E}_{1 / 2} \mathrm{Red}^{1 / 2 / 3 / 4} \\
{[\mathrm{~V}]^{\mathrm{a}}}\end{array}$ & $\begin{array}{c}\mathrm{E}_{\text {номо/Lumо }} \\
{[\mathrm{eV}]^{\mathrm{b}}}\end{array}$ & $\begin{array}{c}\mathrm{E}_{\mathrm{g}}^{\mathrm{CV}} \\
{[\mathrm{eV}]^{\mathrm{c}}}\end{array}$ \\
\hline Dyad $\mathbf{1}$ & $0.25 / 0.61$ & $\begin{array}{c}-1.14 /-1.39 / \\
-1.52 /-2.02\end{array}$ & $-5.30 /-4.03$ & 1.27 \\
$\mathbf{8}$ & $0.23 / 0.61$ & $-1.47^{\mathrm{d}}$ & $-5.26 /-3.73$ & 1.53 \\
$\mathrm{PC}_{61} \mathrm{BM}$ & $-/-$ & $-1.12 /-1.51 /$ & $-6.16 \mathrm{e} /-4.06$ & 2.10 \\
\hline
\end{tabular}

${ }^{a}$ Measured in dichloromethane/0.1 $\mathrm{M}$ tetrabutylammonium hexafluorophosphate at $295 \mathrm{~K}$, scan speed $100 \mathrm{mV} \mathrm{s}^{-1}$, versus ferrocene/ferricenium $\left(\mathrm{Fc} / \mathrm{Fc}^{+}\right)$. ${ }^{\mathrm{b}} \mathrm{Calculated}$ from the onset of the first oxidation and reduction wave and referenced to $\mathrm{Fc} / \mathrm{Fc}^{+}$at $-5.1 \mathrm{eV}$ vs. vacuum. ' $\mathrm{E}_{\text {номо- }}$

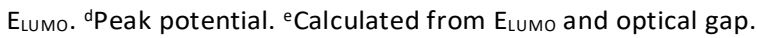

Solution-processed BHJSCs with the simplified device structure glass/ITO/PEDOT:PSS/dyad 1/LiF/Al were fabricated and optimized by variation of layer thickness and SVA using tetrahydrofurane (THF) (Table S1), carbon disulfide ( $\mathrm{CS}_{2}$ ) (Table S2), and chloroform (CF) (Table S3) as solvents under ambient conditions. Measured photovoltaic parameters of the optimized pristine and the post-treated SMOSCs are listed in Table 3. Current density-voltage $(J-V)$ curves of the pristine and of the post-treated SMOSCs are depicted in Fig. 2.

As-cast SMOSCs with an optimized layer thickness of $\approx 100 \mathrm{~nm}$ showed a short circuit current $\left(\mathrm{J}_{\mathrm{sc}}\right)$ of $5.55 \mathrm{~mA} \mathrm{~cm}^{-2}$, an open circuit voltage $\left(V_{O C}\right)$ of $0.86 \mathrm{~V}$, and a fill factor $(F F)$ of 0.35 resulting in a PCE of $1.66 \%$. Post-treatment of the devices by SVA substantially increased the photovoltaic parameters, whereupon $\mathrm{CF}$ after 25 seconds gave superior values than THF or $\mathrm{CS}_{2}$. With $J_{\mathrm{sC}}$ of $9.21 \mathrm{~mA} \mathrm{~cm}^{-2}, \mathrm{FF}$ of 0.45 , and $V_{\mathrm{OC}}$ of $0.82 \mathrm{~V}$ PCE was doubled to $3.39 \%$ compared to the untreated devices. This optimized device slightly outperforms the so far best oligomeric SMOSC ${ }^{13}$ mainly due to increased $J_{\text {Sc }}$. In both cases, the FF $(<0.5)$ is relatively low and limiting PCE which can be attributed to increased geminate and nongeminate recombination of the charge carriers. ${ }^{22}$ The film morphology of the best polymeric SMOSC could be optimized by thermal annealing to yield a substantially higher FF of 0.65 contributing to a record PCE of $6.3 \% .^{9}$

It is interesting to note that a structurally related D-A dyad comprising a septithiophene donor with a pendant $\mathrm{C}_{60}$ acceptor group gave a PCE of only $0.15 \%$ in SMOSCs. ${ }^{23}$
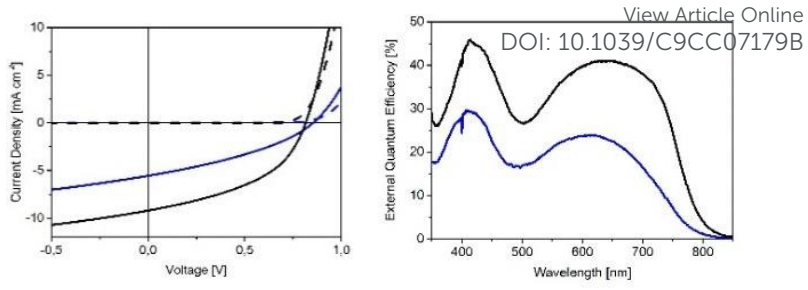

Fig. $2 \mathrm{~J}$-V-characteristics of dyad 1 before (blue) and after SVA (CF $25 \mathrm{~s}$, black) under illumination (full line) and in the dark (dotted line) using the cell architecture: glass/ITO/PEDOT:PSS/dyad 1/LiF/Al (left). EQE spectra of the best performing SMOSC before (blue curve) and after SVA (CF 25 s, black curve) (right).

Table 3 Photovoltaic parameters of SMOSCs with glass/ITO/PEDOT: PSS/dyad 1/LiF/Al, as cast and best value after SVA.

\begin{tabular}{c|c|cccc}
\hline & SVA & $\begin{array}{c}V_{\text {oc }} \\
{[\mathrm{V}]}\end{array}$ & $\begin{array}{c}J_{\text {SC }} \\
{\left[\mathrm{mA} / \mathrm{cm}^{2}\right]}\end{array}$ & FF & $\begin{array}{c}\text { PCE } \\
{[\%]}\end{array}$ \\
\hline \multirow{2}{*}{ Dyad 1 } & - & $\begin{array}{c}0.86 \pm 0.01 \\
(0.86)\end{array}$ & $\begin{array}{c}5.38 \pm 0.23 \\
(5.55)\end{array}$ & $\begin{array}{c}0.35 \pm 0.01 \\
(0.35)\end{array}$ & $\begin{array}{c}1.60 \pm 0.06 \\
(1.66)\end{array}$ \\
\hline \multirow{2}{*}{ Dyad 1 } & THF & $0.80 \pm 0.01$ & $8.48 \pm 0.19$ & $0.40 \pm 0.01$ & $2.73 \pm 0.06$ \\
& $30 \mathrm{~s}$ & $(0.81)$ & $(8.70)$ & $(0.41)$ & $(2.82)$ \\
& $\mathrm{CS} 2$ & $0.79 \pm 0.01$ & $8.78 \pm 0.27$ & $0.42 \pm 0.01$ & $2.95 \pm 0.09$ \\
Dyad 1 & $20 \mathrm{~s}$ & $(0.80)$ & $(9.07)$ & $(0.43)$ & $(3.07)$ \\
& $\mathrm{CF}$ & $0.82 \pm 0.01$ & $9.17 \pm 0.06$ & $0.45 \pm 0.01$ & $\mathbf{3 . 3 5 \pm 0 . 0 2}$ \\
Dyad 1 & $25 \mathrm{~s}$ & $(0.83)$ & $(9.21)$ & $(0.45)$ & $\mathbf{( 3 . 3 9 )}$ \\
\hline
\end{tabular}

Average values for 4 devices \pm standard deviation (best value).

In order to gain insight into the charge generation processes, external quantum efficiency (EQE) measurements were performed for the optimized as-cast solar cell in comparison to the post-treated by SVA (Fig. 2, right). An efficient photon-to-charge conversion was observed over a broad range of the visible spectrum, and SVA with CF led to a strong increase of EQE $E_{\max } @ 414$ nm from 29\% to 46\% and @ 618 nm from 23\% to 41\%. The shape of both EQE spectra are very similar to those of the comparable binary system. ${ }^{15}$ In UV-vis spectra of as-cast and post-treated photoactive layers of dyad $\mathbf{1}$ bathochromic shifts are observed for the absorption bands of the donor moiety concomitant with an intensification of the CT-band at $656 \mathrm{~nm}$ and appearance of a shoulder at lower energy. The absorption band at $334 \mathrm{~nm}$ which corresponds to the fullerene unit of dyad $\mathbf{1}$ is not affectted by SVA (Fig. S10). These results indicate rearrangement of the donor moieties by $\pi-\pi$ stacking which is also described for similar oligomeric donors in binary systems. ${ }^{15,24}$

The electrical characteristics of D-A dyad $\mathbf{1}$ were investigated through fabrication and characterization of organic field-effect transistors (OFET) in bottom-contact bottom-gate configuration prior and after SVA with $\mathrm{CS}_{2}$ (Table S4). ${ }^{25}$ Prior to the surface treatment, transfer curves in unoptimized devices revealed ambipolar charge transport with hole and electron mobilities of respectively $4.7 \times 10^{-6} \mathrm{~cm}^{2} / \mathrm{Vs}$ and $2.9 \times 10^{-5} \mathrm{~cm}^{2} / \mathrm{Vs}$ (Fig. S11). SVA resulted in a 5 to 6 -fold increase of the hole mobility and a more modest increase of the electron mobility by a factor of ca. 3. This increase in hole mobility can be partially attributed to the increased intermolecular packing by $\pi-\pi$ stacking of the donor moieties as was evidenced as well by absorption spectra (Fig. S10). The obtained mobility values of ca. $3 \times 10^{-4} \mathrm{~cm}^{2} / \mathrm{Vs}$ (hole) and $10^{-4} \mathrm{~cm}^{2} / \mathrm{Vs}$ (electron) are surprisingly high for a D-A 
molecule and come into the range of good biphasic morphologies of efficient BHJSCs. Interestingly, the trend in ambipolar charge transport is well reflected in the photovoltaic performance of the SMOSCs of dyad $\mathbf{1}$ in which the PCE is doubled after SVA.

In order to characterize and rationalize the impact of SVA on the nanomorphology of the photoactive layer of dyad $\mathbf{1}$, we investigated the surface by means of tapping mode atomic force microscopy (AFM). Topography images for the as-cast films revealed a tightly packed morphology comprising small grains of 5-10 $\mathrm{nm}$ with a lack of relevant phase contrast suggesting fine mixture of the moieties of dyad $\mathbf{1}$. The SVA-treatment yielded a major morphological change into larger grains with diameters of 20-60 nm (Fig. S12). The effect of SVA on the morphology correlates well with the changes in the device performance, i.e., photovoltaic and transport properties. GIXRD and TEM measurements did not show any crystallinity of the photoactive layers (Fig. S13) nor phase-separated features, respectively (Fig. S14). We rationalize from these first results that an only few nanometer thin phase separation below the resolution limit of the characterisation methods is obtained.

In summary, we reported a novel oligomeric dyad $\mathbf{1}$ comprising a dithienopyrrol-based donor linked to a fullerenic acceptor through a flexible 10 atoms long non-conjugated spacer. Optical and electrochemical characterization of 1 revealed that the absorption spectrum and cyclic voltammogram are composed of a superimposition of the individual units, donor 8 and $\mathrm{PC}_{61} \mathrm{BM}$. The favourable absorption profile and energy levels of the frontier orbitals allowed for application of dyad $\mathbf{1}$ as photoactive layer in solution-processed SMOSCs. After post-treatment by solvent vapour annealing, devices with doubled PCE of $3.4 \%$ were achieved despite a relatively low FF. Ambipolar charge transport was measured in organic field-effect transistors for films of dyad 1 to determine well balanced hole and electron mobilities after SVA indicating that the typical physical elementary processes in biphasic devices are also operative in single material cells. Investigation on film morphology of dyad $\mathbf{1}$ indicate a very fine phase separation. In this respect, more in-depth investigation on film characteristics and long term stability tests are on-going. SMOSCs based on oligomeric and structurally defined molecular materials should become technologically considerably interesting in particular in view of its potentially up-scalable synthesis.

\section{Conflicts of interest}

There are no conflicts to declare.

\section{Acknowlegdements}

PS acknowledges funding from the Agence Nationale de la Recherche through the Labex project CSC (ANR-10-LABX-0026 $\mathrm{CSC}$ ).

\section{Notes and references}

1 H. Sun, T. Liu, J. Yu, T.-K. Lau, G. Zhang, Y. Zhang, M. Su, Y. Tang, R. Ma, B. Liu, J. Liang, K. Feng, X. Lu, X. Guo, F. Gao and H. Yan, Energy Environ. Sci. 2019, advanced article.

2 D. Rasi and R. A. J. Janssen, Adv. Mater. 2018, 31, 1806499.
3 S. Gevorgyan, I. Heckler, E. Bundgaard, M. Verazza ${ }_{0 n}$ Me

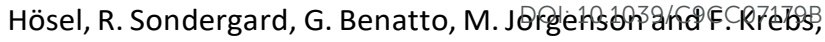
J. Phys D: Appl. Phys. 2017, 50, 103001.

4 J. Roncali and I. Grosu, Adv. Sci. 2019, 6, 1801026.

5 Y. He, T. Heumüller, W. Lai, G. Feng, A. Classen, X. Du, C. Liu, W. Li, N. Li and C. Brabec, Adv. Energy Mater. 2019, 9, 1900409.

6 J.-F. Eckert, J.-F. Nicoud, J.-F. Nierengarten, S.-G. Lin, L. Echegoyen, F. Barigelleti, N. Armaroli, L. Ouali, V. Krasnikov and G. Hadziiouannou, J. Am. Chem. Soc. 2000, 122, 74677474.

7 A. Marcos Ramos, M. T. Rispens, J. K. J. van Duren, J. C. Hummelen and R. A. J. Janssen, J. Am. Chem. Soc. 2001, 123, 6714-6715.

8 J. Roncali, Adv. Energy Mater. 2011, 1, 147-160.

9 G. Feng, J. Li, Y. He, W. Zheng, J. Wang, C. Li, Z. Tang, A. Osvet, N. Li, C. J. Brabec, Y. Yi, H. Yan and W. Li, A. B. Tamayo, B. Walker and T.-Q. Nguyen, Joule 2019, 3, 1765-1781.

10 J. Roncali, P. Leriche and P. Blanchard, Adv. Mater. 2014, 26, 3821-3838.

11 J. Qu, B. Gao, H. Tian, X. Zhang, Y. Wang, Z. Xie, H. Wang, Y. Geng and F. Wang, J. Mater. Chem. A 2014, 2, 3626-3635.

12 L. Bu, X. Guo, B. Yu, Y. Fu, Y. Qu, Z. Xie, D. Yan, Y. Geng and F. Wang, J. Am. Chem. Soc. 2009, 131, 13242-13243.

13 W. Wang, R. Sun, J. Guo, J. Guo and J. Min, Angew. Chem., Int. Ed. 2019, advanced article.

14 T. L. Nguyen, T. H. Lee, B. Gautam, S. Y. Park, K. Gundogdu, J. Y. Kim and H. Y. Woo, Adv. Funct. Mater, 2017, 27, 1702474.

15 S. Dkhil, M. Pfannmöller, I. Ata, D. Duché, M. Gaceur, T. Koganezawa, N. Yoshimoto, J. Simon, L. Escoubas, C. Videlot-Ackermann, O. Margeat, S. Bals, P. Bäuerle and J. Ackermann, J. Mater. Chem. A, 2017, 5, 1005-1013.

16 F. Li, S. Wang, Y. Zhang and J. L. Lutkenhaus, Chem. Mater. 2018, 30, 5169-5174.

17 I. Ata, S. Dkhil, M. Pfannmöller, S. Bals, D. Duché, J. Simon, T. Koganezawa, N. Yoshomoto, C. Videlot-Ackermann, O. Margeat, J. Ackermann and P. Bäuerle, Org. Chem. Front. 2017, 4, 1561-1573.

18 C. Wessendorf, G. Schulz, A. Mishra, P. Kar, I. Ata, M. Weidelener, M. Urdanpilleta, J. Hanisch, E. Mena-Osteritz, M. Linden, E. Ahlswede and P. Bäuerle, Adv. Energy Mater, 2014, 4, 1400266.

19 K. Schulze, C. Uhrich, R. Schüppel, K. Leo, M. Pfeiffer, E. Brier, E. Reinold and P. Bäuerle, Adv. Mater. 2006, 18, 2872-2875.

20. S. Izawa, K. Hashimoto and K. Tajima, Synth. Met., 2012, 162, 2201-2205.

21. T. Nishizawa, K. Tajima and K. Hashimoto, Chem. Commun. 2009, 2469-2471.

22. G. F. A. Dibb, F. C. Jamieson, A. Maurano, J. Nelson and J. R. Durrant, J. Phys. Chem. Lett. 2013, 4, 803-808.

23. T. Nishizawa, H. K. Lim, K. Tajima and K. Hashimoto, J. Mater. Chem. 2007, 17, 2440-2445.

24 B. Qu and J. Wang, Phys. Chem. Chem. Phys., 2013, 15, 89728982.

25 T. Leydecker, M. A. Squillaci, F. Liscio, E. Orgiu and P. Samorì, Chem. Mater., 2019, 31, 6491-6498. 